\title{
INFLUENCE OF ALUMINIUM PRECURSOR ON PHYSICO-CHEMICAL PROPERTIES OF ALUMINIUM HYDROXIDES AND OXIDES Part I. $\mathrm{AlCl}_{3} \cdot 6 \mathrm{H}_{2} \mathrm{O}$
}

\author{
Barbara Pacewska*, Olga Kluk-Płoskońska and D. Szychowski
}

Warsaw University of Technology, Faculty of Building Engineering, Mechanics and Petrochemistry, Instytute of Chemistry, Łukasiewicza 17 St., 09-400 Płock, Poland

An attempt to obtain aluminium hydroxide that could give aluminium oxides of increased thermal stability was made. Aluminium hydroxide was precipitated during a hydrolysis of aluminium chloride in ammonia medium. The influence of preparative conditions, such as a dosing rate of aluminium precursor, $\mathrm{pH}$, duration of the precipitate refluxing and temperature of calcination, on the properties of obtained hydroxides and oxides was investigated. The materials were studied with the following methods: thermal analysis, IR spectroscopy, low-temperature nitrogen adsorption and adsorption-desorption of benzene vapours.

Precipitated boehmites had high values of $S_{\mathrm{BET}}$ determined from nitrogen adsorption $\left(220-300 \mathrm{~m}^{2} \mathrm{~g}^{-1}\right)$, good sorption capacity for benzene vapours, developed mesoporous structure and hydrophilic character. It has been proved that a high $\mathrm{pH}$ value during the precipitation of aluminium hydroxide favoured better crystallisation of boehmite structure, higher temperature of its dehydroxylation into $\gamma-\mathrm{Al}_{2} \mathrm{O}_{3}$, and delayed transformation of $\gamma$ phase into $\alpha-\mathrm{Al}_{2} \mathrm{O}_{3}$. Aluminium oxides derived from the hydroxides precipitated at a high $\mathrm{pH}$ were the most stable at high temperatures, and were characterised with the best surface properties.

Keywords: boehmite, metastable aluminium oxides, thermal decomposition

\section{Introduction}

The aluminium oxo-hydroxide is a two-component system built up from $\mathrm{Al}, \mathrm{O}$ atoms, $\mathrm{OH}^{-}$groups and water molecules. The network may consist of ribbonlike fibres, as well as monodisperse spherical particles; it can be microcrystalline and partially or totally amorphous depending on methods and conditions of preparation [1]. Among popular methods investigated recently there are: synthesis from metal-organic precursors (so-called sol-gel method), co-precipitation and precipitation from homogenous solutions [2]. The heterogeneous precipitation is more conventional technique and it is still powerful and widely used; however many research works must be undertaken to estimate the influence of preparative conditions (such as a dosing rate of reagents, $\mathrm{pH}$, duration of digestion and temperature of calcination) on the form of obtained precipitates and properties of the products of its calcination.

Hwang et al. [3] precipitated aluminium hydrates using $\mathrm{AlCl}_{3} \cdot 6 \mathrm{H}_{2} \mathrm{O}$ and $\mathrm{NH}_{3} \cdot \mathrm{H}_{2} \mathrm{O}$ at $\mathrm{pH}$ equal $7,8,9$ or 10 . As the $\mathrm{pH}$ value increased from 7 to 10 phases of obtained aluminium hydrates changed from amorphous to boehmite, bayerite, nordstrandite, which was attributed to an increased amount of $\mathrm{OH}^{-}$ions from added $\mathrm{NH}_{3} \cdot \mathrm{H}_{2} \mathrm{O}$. The influence of calcination tempera- ture from the range $600-1300^{\circ} \mathrm{C}$ on the thermal transformation of aluminium hydrates was investigated, too. All precipitates converted into $\alpha-\mathrm{Al}_{2} \mathrm{O}_{3}$ via $\gamma-, \delta$ and $\theta-\mathrm{Al}_{2} \mathrm{O}_{3}$, however process of dehydration to $\gamma-\mathrm{Al}_{2} \mathrm{O}_{3}$, as well as transformation to corundum conducted at lower temperatures in powders precipitated under low pH value. Musić et al. revealed [4] that lower $\mathrm{pH}$ values result in forming boehmite, whereas higher $\mathrm{pH}$ values lead to bayerite formation, and a slight change of $\mathrm{pH}$ in alkaline medium has a significant effect on the ratio of bayerite to boehmite at the beginning of the precipitation process. The authors of [5] evidenced the importance of $\mathrm{pH}$ and temperature values on the final product morphology (fibres or porous aggregates). Boehmite particles were synthesized with using $\mathrm{Al}\left(\mathrm{NO}_{3}\right)_{3} \cdot 9 \mathrm{H}_{2} \mathrm{O}$ and $\mathrm{NaOH}$ in conditions of controlled $\mathrm{pH}$ and temperature. The product obtained at $80^{\circ} \mathrm{C}$ and $\mathrm{pH}=8$ (the conjunction of a sufficiently high temperature and $\mathrm{pH}$ ) constituted of polycrystalline fibres of a diameter from the range $3-8 \mathrm{~nm}$ and length equal approximately $100 \mathrm{~nm}$. This was a porous material with high specific surface area $\left(\sim 352 \mathrm{~m}^{2} \mathrm{~g}^{-1}\right)$ and porous volume $\left(\sim 0.8 \mathrm{~cm}^{3} \mathrm{~g}^{-1}\right)$. The precipitate obtained at $20^{\circ} \mathrm{C}$ and $\mathrm{pH}=5$ was amorphous with the specific surface area of about $72 \mathrm{~m}^{2} \mathrm{~g}^{-1}$ and a pore volume $0.4 \mathrm{~cm}^{3} \mathrm{~g}^{-1}$. On the basis of the investigations conducted for the samples prepared at $\mathrm{pH}=9$ and

Author for correspondence: ich@zto.pw.plock.pl 
at varying temperature, as well as obtained at $60^{\circ} \mathrm{C}$ and varying $\mathrm{pH}$, it was concluded that higher temperature leads to better crystallinity, higher specific surface and higher porous volume, whereas the higher $\mathrm{pH}$ the better crystallinity (however at $\mathrm{pH} \geq 10$ a bayerite consisted of large crystallites was formed simultaneously to the boehmite phase). The way in which the $\mathrm{pH}$ value influences thermal stability of aluminium oxides obtained from boehmite through calcination process was the purpose of investigations described in [6]. Boehmite was prepared in a precipitation process from $\mathrm{Al}\left(\mathrm{NO}_{3}\right)_{3} \cdot 9 \mathrm{H}_{2} \mathrm{O}$ with $\mathrm{NH}_{3} \cdot \mathrm{H}_{2} \mathrm{O}$ at $\mathrm{pH}=6$ or 7 , and then subjected to ageing in the mother liquor for $264 \mathrm{~h}$ at elevated temperature. The authors revealed that aluminium oxides obtained during calcination at $1200^{\circ} \mathrm{C}$ of aluminium hydroxides precipitated at lower $\mathrm{pH}=6$ (undigested, as well as digested for $264 \mathrm{~h}$ ) contained more $\alpha$ phase than the respective samples prepared at a higher $\mathrm{pH}$ and were characterised by lower values of specific surface.

As the process of digestion used by the authors [6] is known to improve thermal stability of $\gamma-\mathrm{Al}_{2} \mathrm{O}_{3}$ through the removal of defect sites in the crystallites and inhibition of the surface diffusion necessary for crystallite growth [7], it is a subject of extended research works. Chuagh et al. [7] made an attempt to evaluate the surface properties of aluminium hydroxides prepared at $\mathrm{pH}=6$ from $\mathrm{Al}\left(\mathrm{NO}_{3}\right)_{3} \cdot 9 \mathrm{H}_{2} \mathrm{O}$ and $\mathrm{NH}_{3} \cdot \mathrm{H}_{2} \mathrm{O}$ solutions after subjecting them to the process of digestion for $24,48,96$, 192 and $384 \mathrm{~h}$, as well as thermal stability of $\gamma-\mathrm{Al}_{2} \mathrm{O}_{3}$ obtained from these hydroxides. It was shown that the freshly precipitated gel (pseudoboehmite) had a very low surface area $\left(\sim 35 \mathrm{~m}^{2} \mathrm{~g}^{-1}\right)$, however the surface area increased after digestion of the hydroxide in the mother liquor $\left(307 \mathrm{~m}^{2} \mathrm{~g}^{-1}\right.$ after $384 \mathrm{~h}$ of ageing). After calcination at $500^{\circ} \mathrm{C}$ the resulting alumina had a surface area of $230-310 \mathrm{~m}^{2} \mathrm{~g}^{-1}$ depending on the length of digestion. The aged aluminas were characterised with higher porosity, higher surface area and better stability than the undigested sample. These properties showed correlation with digestion time of hydroxides. Aluminas prepared from aged precursors were able to withstand calcination to $1200^{\circ} \mathrm{C}$ maintaining a surface area of about $68 \mathrm{~m}^{2} \mathrm{~g}^{-1}$. Moreover, the transformation into $\alpha-\mathrm{Al}_{2} \mathrm{O}_{3}$ was delayed in case of these samples. Musić et al. [8] investigated the product of precipitation at $\mathrm{pH} \sim 8$ from $\mathrm{Al}\left(\mathrm{NO}_{3}\right)_{3} \cdot 9 \mathrm{H}_{2} \mathrm{O}$ with $\mathrm{NH}_{3} \cdot \mathrm{H}_{2} \mathrm{O}$ after its autoclaving for varying time intervals $(1,6,24,72$ and $86 \mathrm{~h})$. The process of precipitation resulted in boehmite that after $1 \mathrm{~h}$ of autoclaving showed surface area of $164 \mathrm{~m}^{2} \mathrm{~g}^{-1}$. The value of specific surface area increased to $246 \mathrm{~m}^{2} \mathrm{~g}^{-1}$ after $6 \mathrm{~h}$ of ageing, and then decreased with an increase in crystallinity. For the best-crystallized boehmite powder, the smallest specific surface area $\left(91 \mathrm{~m}^{2} \mathrm{~g}^{-1}\right)$ was measured. According to authors, the increase in crystallite size and crystallinity improvement decreased the internal, as well as external surfaces of the particles, which was reflected in the values of the specific surface area of boehmite powders. The conditions of hydrothermal process on the microstructural properties of boehmite formed in an alkaline medium were the subject of an interest of the authors of [4]. The main product of the precipitation from $\mathrm{Al}\left(\mathrm{NO}_{3}\right)_{3} \cdot 9 \mathrm{H}_{2} \mathrm{O}$ and $\mathrm{NaOH}$ solutions was bayerite, which after digestion at $160^{\circ} \mathrm{C}$ for $5 \mathrm{~h}$ completely converted into boehmite via the dissolution/re-precipitation mechanism. Boehmite crystallities were in the nanosize range and possessed an anisotropic shape. A tendency to increased crystallite size with prolonged heating time was evident. The particles of boehmite produced by autoclaving for $10 \mathrm{~h}$ were in the form of thin foils of varying size. Their morphology was different in relation to those usually obtained for boehmite (rods, fibres and very small plates). Since the crystallite sizes of this boehmite sample were in nanosize range, it was concluded that the particles consisted of nanosized boehmite crystallites.

The main goal of the present study was to evaluate the preparative conditions $(\mathrm{pH}$, dosing rate of aluminium precursor and duration of precipitate digestion) for preparing aluminium oxo-hydroxide, as a material which could, in turn, be used for obtaining a low-temperature transition alumina $\left(\gamma-\mathrm{Al}_{2} \mathrm{O}_{3}\right)$ of enhanced stability at high temperatures. The presented paper is a fragment of extensive research works concerning the influence of different aluminium precursors on physicochemical properties of aluminium hydroxides and oxides. In this paper, aluminium chloride is used as the precursor of precipitated hydroxides.

\section{Experimental}

The products of hydrolysis of hydrous aluminium chloride $\mathrm{AlCl}_{3} \cdot 6 \mathrm{H}_{2} \mathrm{O}$ anal. grade produced by $\mathrm{POCh}$ Gliwice, were the main objects of the studies. The hydrolysis process was carried out in ammonia medium as follows:

The substrates (the $0.5 \mathrm{M}$ solution of $\mathrm{AlCl}_{3}$ and $0.75 \mathrm{M}$ solution of $\mathrm{NH}_{3} \cdot \mathrm{H}_{2} \mathrm{O}$ ) were dosed with a peristaltic pump according to a fixed dosing rate to a $1000 \mathrm{~cm}^{3}$ beaker placed in a thermostat. The precipitation was led at $100^{\circ} \mathrm{C}$ with continuous stirring of reagents. The following parameters of the process were kept:

- for the $\mathrm{I}^{\mathrm{st}}$ series: $\mathrm{pH}=7$ and a dosing rate of $\mathrm{AlCl}_{3}$ equal $7 \mathrm{~cm}^{3} \mathrm{~min}^{-1}$ 
- for the $\mathrm{II}^{\text {nd }}$ series: $\mathrm{pH}=7$ and a dosing rate of $\mathrm{AlCl}_{3}$ equal $1 \mathrm{~cm}^{3} \mathrm{~min}^{-1}$

- for the $\mathrm{III}^{\mathrm{rd}}$ series: $\mathrm{pH}=8$ and a dosing rate of $\mathrm{AlCl}_{3}$ equal $7 \mathrm{~cm}^{3} \min ^{-1}$

In each case, the pumping rate of $\mathrm{NH}_{3} \cdot \mathrm{H}_{2} \mathrm{O}$ was regulated in a way securing a demanded $\mathrm{pH}$ value in the solution. A part of the milky-white colloidal precipitate obtained was filtered off, washed with distilled water, dried at $60^{\circ} \mathrm{C}$ in a drier and finally powdered in a mortar. The sample thus obtained was used for further studies. The other part of the reaction mixture was transferred to a round-bottomed flask and heated at $100^{\circ} \mathrm{C}$ under a reflux condenser. The heating was stopped for several night hours, during which the mixture was kept at the temperature of $60^{\circ} \mathrm{C}$ in a drier. The precipitates were digested for $59 \mathrm{~h}$; however a total time of keeping them in mother liquor, including night-time spent in a drier at $60^{\circ} \mathrm{C}$, was $192 \mathrm{~h}$. For the $\mathrm{I}^{\text {st }}$ series precipitates were additionally digested for 20 and $39 \mathrm{~h}$, which corresponded to a total time equal 48 and $96 \mathrm{~h}$. When the required time was over, the precipitate was filtered off, washed with distilled water, dried at $60^{\circ} \mathrm{C}$ in a drier and powdered in a mortar. The obtained in such a way powder samples were used for further studies.

Conditions under which the process of hydrolysis of aluminium chloride was conducted, were chosen on the basis of previous research, as well as of the analysis of literature works quoted in this paper.

The thermal decomposition of the products of hydrolysis of hydrous aluminium chloride in ammonia medium was carried out both under isothermal conditions and under dynamic conditions i.e. under permanent temperature increase.

The partial thermal dissociation of the products of hydrolysis was carried out by their heating in a high-temperature flow reactor (CZYLOK, Poland), leading the calcination process at $550^{\circ} \mathrm{C}$ for $2 \mathrm{~h}$ in air atmosphere. Aluminium oxides obtained at $550^{\circ} \mathrm{C}$ were subjected to a further calcination at 900 or $1200^{\circ} \mathrm{C}$.

The TG, DTA and DTG curves, IR spectra and sorption studies were conducted for the starting product of hydrolysis, as well as for the products of their thermal decomposition under isothermal conditions.

The thermoanalytical curves TG, DTG and DTA were recorded using a thermoanalyser TA Instruments SDT 2960. The measurements were performed for 5-10 mg samples in air atmosphere and in a temperature range of $20-1000^{\circ} \mathrm{C}$, with a heating rate of $10^{\circ} \mathrm{C} \mathrm{min}^{-1}$.

The IR spectra were recorded with a FTIR Matson Spectrophotometer in a wave number range of $4000-400 \mathrm{~cm}^{-1}$. Powders were dispersed in $\mathrm{KBr}$ matrix and pressed into thin, transparent pellets.

The degree of specific surface development was studied by volumetric determination of low-tempera- ture nitrogen adsorption and by the adsorption and desorption of benzene vapours. On the basis of obtained adsorption/desorption isotherms, by means of the programme [9], the following parameters of the porous structure were calculated: specific surface according to BET method $\left(S_{\mathrm{BET}}\right)$, the surface of mesopores $\left(S_{\mathrm{MEZ}}\right)$ from the adsorption and desorption part of the isotherms using Kisielev method, and the distribution of mesopore volume and surface by Dollimore-Hill method.

\section{Results and discussion}

\section{Thermal analysis}

TG and DTA curves of the starting aluminium hydroxides from the $\mathrm{I}^{\text {st }}-\mathrm{III}^{\text {rd }}$ series both undigested and digested at $100^{\circ} \mathrm{C}$ for varying time intervals are presented in Figs 1a and b; whereas Table 1 reveals the values of mass loss for each step of thermal decomposition calculated for all hydroxide samples.

The thermal analysis results show that undigested hydroxides, as well as digested at elevated temperature for varying time intervals decompose in a similar way.

The TG curve evidences two-step decomposition of the samples (Fig. 1a). In the first step ranging from 20 to $170^{\circ} \mathrm{C}$, the samples lose humidity water. This endothermic effect is reflected as a peak on the DTA curve with an extremum at $60-80^{\circ} \mathrm{C}$ (Fig. 1b). The mass loss values calculated for digested hydroxides of all series are lower than these for the samples not subjected to the process of ageing (Table 1), which points at smaller amount of physically adsorbed water in them.

In the second step, corresponding to the temperature range $170-550^{\circ} \mathrm{C}$, the samples lose a further

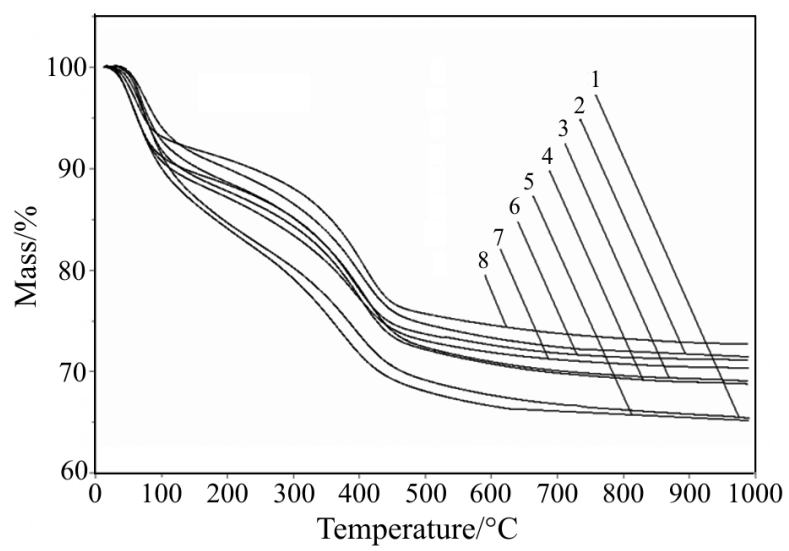

Fig. 1a TG curves for aluminium hydroxides from the $\mathrm{I}^{\mathrm{st}}-\mathrm{III}^{\mathrm{rd}}$ series both undigested and digested for varying time intervals; $1-\mathrm{Al}(\mathrm{OH})_{3} \backslash I \backslash 0 \mathrm{~h}, 2-\mathrm{Al}(\mathrm{OH})_{3} \backslash I \backslash 20 \mathrm{~h}$, $3-\mathrm{Al}(\mathrm{OH})_{3} \backslash \mathrm{I} \backslash 39 \mathrm{~h}, 4-\mathrm{Al}(\mathrm{OH})_{3} \backslash \mathrm{I} \backslash 59 \mathrm{~h}$, $5-\mathrm{Al}(\mathrm{OH})_{3} \backslash \mathrm{II} \backslash 0 \mathrm{~h}, 6-\mathrm{Al}(\mathrm{OH})_{3} \backslash \mathrm{II} \backslash 59 \mathrm{~h}$, $7-\mathrm{Al}(\mathrm{OH})_{3} \backslash \mathrm{III} \backslash 0 \mathrm{~h}, 8-\mathrm{Al}(\mathrm{OH})_{3} \backslash \mathrm{III} \backslash 59 \mathrm{~h}$ 


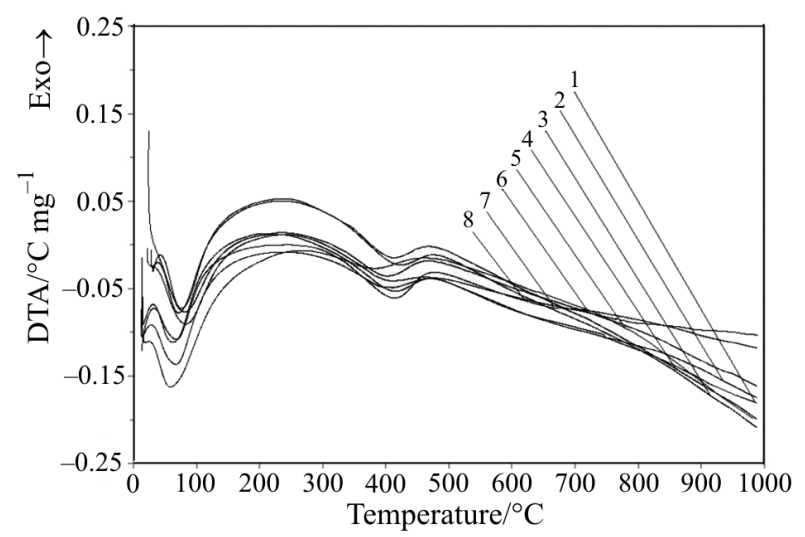

Fig. 1b DTA curves for aluminium hydroxides from the $\mathrm{I}^{\mathrm{st}}-\mathrm{III}^{\mathrm{rd}}$ series both undigested and digested for varying time intervals; $1-\mathrm{Al}(\mathrm{OH})_{3} \backslash \mathrm{I} \backslash 0 \mathrm{~h}, 2-\mathrm{Al}(\mathrm{OH})_{3} \backslash \mathrm{I} \backslash 20 \mathrm{~h}$, $3-\mathrm{Al}(\mathrm{OH})_{3} \backslash \backslash \backslash 39 \mathrm{~h}, 4-\mathrm{Al}(\mathrm{OH})_{3} \backslash I \backslash 59 \mathrm{~h}$, $5-\mathrm{Al}(\mathrm{OH})_{3} \backslash \mathrm{II} \backslash 0 \mathrm{~h}, 6-\mathrm{Al}(\mathrm{OH})_{3} \backslash \mathrm{II} \backslash 59 \mathrm{~h}$, $7-\mathrm{Al}(\mathrm{OH})_{3} \backslash \mathrm{IIII} \backslash 0 \mathrm{~h}, 8-\mathrm{Al}(\mathrm{OH})_{3} \backslash \mathrm{III} \backslash 59 \mathrm{~h}$

$17-18,16-18$ and $14-16 \%$ of their masses, respectively, for the hydroxides from the $\mathrm{I}^{\text {st }}-\mathrm{III}^{\text {rd }}$ series (Table 1). These values correspond to the loss of 1.4-1.5; 1.3-1.6 and 1.1-1.3 mol of water per $1 \mathrm{~mol}$ of $\mathrm{Al}_{2} \mathrm{O}_{3}$. Taking into account that decomposition of boehmite takes place at $410^{\circ} \mathrm{C}[10]$ according to the reaction:

$$
2 \mathrm{AlO}(\mathrm{OH}) \rightarrow \gamma-\mathrm{Al}_{2} \mathrm{O}_{3}+\mathrm{H}_{2} \mathrm{O}
$$

and that this process is accompanied by the loss of 1 particle of water, which corresponds to the theoretical mass loss of $15 \%$, one may suppose that examined samples contained mainly boehmite that decomposed according to the above reaction. This stage of decomposition is reflected on the DTA curve as an endothermic effect with an extremum ranging from 380 to $420^{\circ} \mathrm{C}$. The value of this extremum is shifted to higher temperatures for the hydroxides of III $\backslash 0 \mathrm{~h}$ and
III $59 \mathrm{~h}$ series precipitated at higher $\mathrm{pH}$. It confirms the conclusion made by the authors of [3] that higher $\mathrm{pH}$ value favours higher temperature of boehmite dehydroxylation into $\gamma-\mathrm{Al}_{2} \mathrm{O}_{3}$.

\section{FTIR spectroscopy}

Figure 2a represents the IR spectra recorded for the product of hydrolysis of aluminium chloride in ammonia medium from $\backslash \backslash 0 \mathrm{~h}$ series and the products of its calcination for $2 \mathrm{~h}$ at 550,900 or $1200^{\circ} \mathrm{C}$; Fig. $2 \mathrm{~b}$ shows the IR spectra of aluminium hydroxides from $\mathrm{I} \backslash 0 \mathrm{~h}, \mathrm{II} \backslash 0 \mathrm{~h}$ and III $\backslash 0 \mathrm{~h}$ series, as well as the hydroxides from I $\backslash 59 \mathrm{~h}, \mathrm{II} \backslash 59 \mathrm{~h}$ and III $\backslash 59 \mathrm{~h}$ series, whereas Fig. 2c demonstrates the IR spectra of aluminium oxides prepared from these hydroxides through calcination at $1200^{\circ} \mathrm{C}$.

The IR spectra of aluminium hydroxides and the products of their calcination at 550,900 or $1200^{\circ} \mathrm{C}$ recorded for undigested samples from I $\backslash 0 \mathrm{~h}, \mathrm{II} \backslash 0 \mathrm{~h}$ and III $\backslash 0 \mathrm{~h}$ series are similar to the respective IR spectra obtained for analogous samples digested for varying time intervals.

In the spectra recorded for all hydroxides, there is a broad band at the wave number range of $3700-2900 \mathrm{~cm}^{-1}$ ascribed to stretching vibrations of OH groups in the hydroxide structure, as well as in water physically adsorbed [11]. Within this band, another weaker one is observed at about $3029 \mathrm{~cm}^{-1}$ characteristic for stretching vibrations of $\mathrm{OH}$ groups in boehmite $[12,13]$. A weakly visible band for deformation vibrations of this group is identified at $1155 \mathrm{~cm}^{-1}$ [14]. The band at $900 \mathrm{~cm}^{-1}$ is due to vibrational modes localized in the surface layer and most likely involving the deformation of surface $\mathrm{OH}$ groups in $\gamma-\mathrm{AlOOH}$ [15]. The formation of boehmite structure in the samples is also con-

Table 1 The mass loss values for individual steps of thermal decomposition calculated for hydroxide samples of the $\mathrm{I}^{\mathrm{st}}-\mathrm{III}^{\mathrm{rd}}$ series, both undigested and digested for 20,39 or $59 \mathrm{~h}$

\begin{tabular}{|c|c|c|c|c|c|c|}
\hline \multirow{3}{*}{ Sample } & \multicolumn{6}{|c|}{ Temperature range $/{ }^{\circ} \mathrm{C}$} \\
\hline & \multicolumn{2}{|c|}{$20-170$} & \multicolumn{2}{|c|}{$170-550$} & \multicolumn{2}{|c|}{$20-1000$} \\
\hline & Mass loss $/ \%$ & $\mathrm{Al}_{2} \mathrm{O}_{3} \cdot n \mathrm{H}_{2} \mathrm{O}$ & Mass loss $/ \%$ & $\mathrm{Al}_{2} \mathrm{O}_{3} \cdot n \mathrm{H}_{2} \mathrm{O}$ & Mass loss $/ \%$ & $\mathrm{Al}_{2} \mathrm{O}_{3} \cdot n \mathrm{H}_{2} \mathrm{O}$ \\
\hline \multicolumn{7}{|c|}{$\mathrm{I}^{\mathrm{st}}$ series } \\
\hline $\mathrm{Al}(\mathrm{OH})_{3} \backslash 0 \mathrm{~h}$ & 13.8 & 1.2 & 17.8 & 1.5 & 34.5 & 3.0 \\
\hline $\mathrm{Al}(\mathrm{OH})_{3} / 20 \mathrm{~h}$ & 9.2 & 0.7 & 16.9 & 1.4 & 29.3 & 2.4 \\
\hline $\mathrm{Al}(\mathrm{OH})_{3} \mid 39 \mathrm{~h}$ & 10.5 & 0.9 & 17.9 & 1.5 & 31.0 & 2.6 \\
\hline $\mathrm{Al}(\mathrm{OH})_{3} \backslash 59 \mathrm{~h}$ & 11.4 & 0.9 & 17.2 & 1.4 & 31.2 & 2.6 \\
\hline \multicolumn{7}{|c|}{ II $^{\text {nd }}$ series } \\
\hline $\mathrm{Al}(\mathrm{OH})_{3} \backslash 0 \mathrm{~h}$ & 14.5 & 1.2 & 18.3 & 1.6 & 33.9 & 2.9 \\
\hline $\mathrm{Al}(\mathrm{OH})_{3} \backslash 59 \mathrm{~h}$ & 10.9 & 0.9 & 15.9 & 1.3 & 28.8 & 2.3 \\
\hline \multicolumn{7}{|c|}{ III $^{\text {rd }}$ series } \\
\hline $\mathrm{Al}(\mathrm{OH})_{3} \backslash 0 \mathrm{~h}$ & 12.0 & 1.0 & 13.8 & 1.1 & 29.7 & 2.4 \\
\hline $\mathrm{Al}(\mathrm{OH})_{3} \backslash 59 \mathrm{~h}$ & 8.5 & 0.7 & 16.4 & 1.3 & 27.3 & 2.1 \\
\hline
\end{tabular}




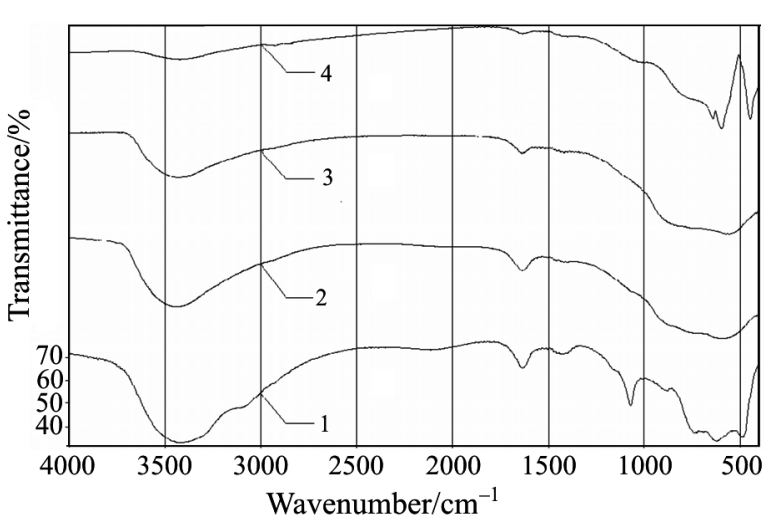

Fig. 2a IR spectra for the samples from the I $\backslash 0 \mathrm{~h}$ series; $1-\mathrm{Al}(\mathrm{OH})_{3} \backslash \mathrm{II} \backslash 0 \mathrm{~h}, 2-\mathrm{Al}_{2} \mathrm{O}_{3} \backslash \mathrm{I} \backslash 0 \mathrm{~h} \backslash 550^{\circ} \mathrm{C}$, $3-\mathrm{Al}_{2} \mathrm{O}_{3} \backslash \mathrm{I} \backslash 0 \mathrm{~h} \backslash 550^{\circ} \mathrm{C} \backslash 900^{\circ} \mathrm{C}$, $4-\mathrm{Al}_{2} \mathrm{O}_{3} \backslash \backslash \backslash 0 \mathrm{~h} \backslash 550^{\circ} \mathrm{C} \backslash 1200^{\circ} \mathrm{C}$

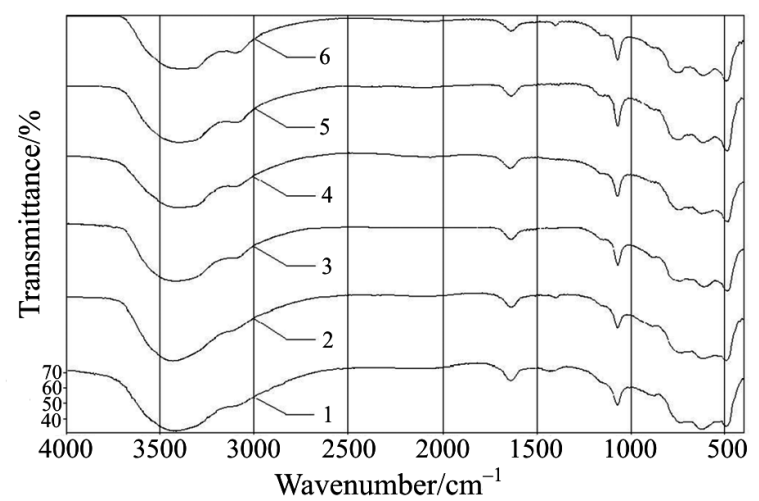

Fig. 2b IR spectra for aluminium hydroxides from the I ${ }^{\text {st }}-\mathrm{III}^{\text {rd }}$ series both undigested and digested for $59 \mathrm{~h}$; $1-\mathrm{Al}(\mathrm{OH})_{3} \backslash \mathrm{I} \backslash 0 \mathrm{~h}, 2-\mathrm{Al}(\mathrm{OH})_{3} \backslash \mathrm{II} \backslash 0 \mathrm{~h}$, $3-\mathrm{Al}(\mathrm{OH})_{3} \backslash \mathrm{III} \backslash 0 \mathrm{~h}, 4-\mathrm{Al}(\mathrm{OH})_{3} \backslash \mathrm{I} \backslash 59 \mathrm{~h}$, $5-\mathrm{Al}(\mathrm{OH})_{3} \backslash \mathrm{II} \backslash 59 \mathrm{~h}, 6-\mathrm{Al}(\mathrm{OH})_{3} \backslash \mathrm{III}$

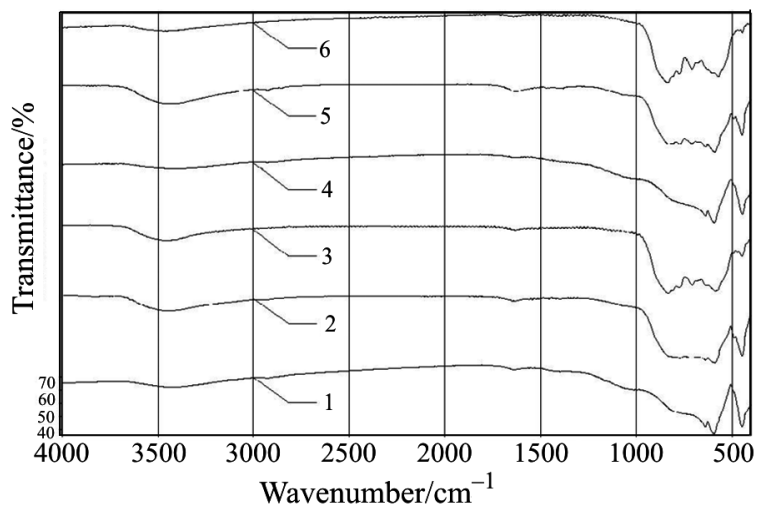

Fig. 2c IR spectra for the products of calcination at $1200^{\circ} \mathrm{C}$ for $2 \mathrm{~h}$ of aluminium hydroxides from the $\mathrm{I}^{\mathrm{st}}-\mathrm{III}^{\mathrm{rd}} \mathrm{se}-$ ries both undigested and digested for $59 \mathrm{~h}$; $1-\mathrm{Al}_{2} \mathrm{O}_{3} \backslash \mathrm{I} \backslash 0 \mathrm{~h} \backslash 550^{\circ} \mathrm{C} \backslash 1200^{\circ} \mathrm{C}$; $2-\mathrm{Al}_{2} \mathrm{O}_{3} \backslash \mathrm{II} \backslash 0 \mathrm{~h} \backslash 550^{\circ} \mathrm{C} \backslash 1200^{\circ} \mathrm{C}$; $3-\mathrm{Al}_{2} \mathrm{O}_{3} \backslash \mathrm{III} \backslash 0 \mathrm{~h} \backslash 550^{\circ} \mathrm{C} \backslash 1200^{\circ} \mathrm{C}$; $4-\mathrm{Al}_{2} \mathrm{O}_{3} \backslash \mathrm{I} \backslash 59 \mathrm{~h} \backslash 550^{\circ} \mathrm{C} \backslash 1200^{\circ} \mathrm{C}$; $5-\mathrm{Al}_{2} \mathrm{O}_{3} \backslash \mathrm{II} \backslash 59 \mathrm{~h} \backslash 550^{\circ} \mathrm{C} \backslash 1200^{\circ} \mathrm{C}$; $6-\mathrm{Al}_{2} \mathrm{O}_{3} \backslash \mathrm{III} \backslash 59 \mathrm{~h} \backslash 550^{\circ} \mathrm{C} \backslash 1200^{\circ} \mathrm{C}$ firmed by a very intensive peak $\sim 1070 \mathrm{~cm}^{-1}$ [15] ascribed to an Al-O vibrational mode $[4,16]$, as well as a broad band at the wave number range of $480-750 \mathrm{~cm}^{-1}$, consisted of three peaks: 741, 610 and $490 \mathrm{~cm}^{-1}$, attributed to 'condensed' $\mathrm{AlO}_{6}$ octahedra. The intensity of these peaks is stronger for the samples aged in mother liquor at elevated temperature with respect to undigested ones (compare the spectra in Fig. 2b). This may evidence that the process of digestion of aluminium hydroxide probably favours the formation of boehmite structure. In the IR spectra of hydroxides from I $20 \mathrm{~h}$, $\mathrm{I} / 39 \mathrm{~h}, \mathrm{I} \backslash 59 \mathrm{~h}$ series any distinct differences in the intensity of peaks characteristic for boehmite are visible, which points at slight influence of digestion time on the formation of boehmite structure.

Except above mentioned bands in the IR spectra of all hdyroxides from the $\mathrm{I}^{\text {st }}-\mathrm{III}^{\text {rd }}$ series, there are another ones such as at $1640 \mathrm{~cm}^{-1}$ ascribed to bending vibrations of $\mathrm{OH}$ groups in structural water [17] and slightly visible bands at $800-920 \mathrm{~cm}^{-1}$ that most likely involve aluminate anions or Al-O-Al coupling formed through condensation.

The process of calcination at $550^{\circ} \mathrm{C}$ for $2 \mathrm{~h}$ for all starting hydroxides led to creation $\gamma-\mathrm{Al}_{2} \mathrm{O}_{3}$. It is confirmed by a strong broad absorption band in the region 750-900 $\mathrm{cm}^{-1}$, due to stretching vibrations of a lattice of interlinked tetrahedra $\mathrm{AlO}_{4}$ [15]. This is in agreement with thermal analysis results. An increase of calcination temperature up to $900^{\circ} \mathrm{C}$ probably results in high-temperature transition oxides such as $\delta$ or $\theta$ of higher crystalline order. This is reflected in the character change of the band at $750-900 \mathrm{~cm}^{-1}$, which becomes broader, stronger and partly resolved into several sharp components of small or medium intensity [15]. Simultaneously, the band in the range of $3700-2900 \mathrm{~cm}^{-1}$ attributed to stretching vibrations of $\mathrm{OH}$ groups in the hydroxide structure, as well as in physically adsorbed water, is becoming weaker and weaker and its intensity is the smallest in the IR spectra of the samples calcined at $1200^{\circ} \mathrm{C}$ (compare in Fig. 2a). The analysis of the IR spectra recorded for the aluminium oxides from the $\mathrm{I}^{\mathrm{st}}$ series calcined $1200^{\circ} \mathrm{C}$ shows the character change of the band at $750-900 \mathrm{~cm}^{-1}$ corresponding to Al-O modes in the lattice. In the IR spectra, new peaks at 465, 610 and $645 \mathrm{~cm}^{-1}$ appear, which are due to vibrations of 'condensed' $\mathrm{AlO}_{6}$ octahedra in $\alpha-\mathrm{Al}_{2} \mathrm{O}_{3}$ [15]. Their intensity is weaker for the oxides prepared from hydroxides from I $\backslash 20 \mathrm{~h}, \mathrm{I} \backslash 39 \mathrm{~h}, \mathrm{I} \backslash 59 \mathrm{~h}$ series in comparison with the sample obtained from the hydroxide $\mathrm{I} \backslash 0 \mathrm{~h}$, however it hardly changes with lengthening of digestion time. The peaks for $\alpha-\mathrm{Al}_{2} \mathrm{O}_{3}$ also appear in the spectra of aluminium oxides from II $\backslash 0 \mathrm{~h}$ and II $\backslash 59 \mathrm{~h}$ series, however of much weaker intensity and they are 
accompanied by another ones at $675,715,770,810$ and $835 \mathrm{~cm}^{-1}$ typical for $\theta-\mathrm{Al}_{2} \mathrm{O}_{3}$ [18].

The character of the IR spectra recorded for analogous samples from III $\backslash 0 \mathrm{~h}$ and III $\backslash 59 \mathrm{~h}$ series is congenial with the respective spectra of oxides from II $\backslash 0 \mathrm{~h}$ and II $\backslash 59 \mathrm{~h}$ series, with such a small difference that the bands characteristic for $\alpha$ phase are much weaker, while the bands typical for $\theta-\mathrm{Al}_{2} \mathrm{O}_{3}-$ much stronger (Fig. 2c). It may proof that a higher $\mathrm{pH}$ value at which aluminium hydroxides from III $\backslash 0 \mathrm{~h}$ and III $\backslash 59 \mathrm{~h}$ series were precipitated favours delayed transformation of $\gamma-\mathrm{Al}_{2} \mathrm{O}_{3}$ obtained from this hydroxide into $\alpha$ phase. This is in agreement with the results of the researchers [3]. On the basis of the investigations described in this paper, it may be concluded that the decrease of precipitation rate is likely to lead to similar results.

\section{Low-temperature nitrogen adsorption}

Table 2 presents the values of specific surface determined by the method of low-temperature nitrogen adsorption for the hydroxides of all series, both undigested and digested for $59 \mathrm{~h}$ (and for I $\backslash 20 \mathrm{~h}, \mathrm{I} \backslash 39 \mathrm{~h}$ series), as well as the products of their calcination at 550,900 or $1200^{\circ} \mathrm{C}$ for $2 \mathrm{~h}$.

An analysis of the data collected in Table 2 shows that freshly precipitated aluminium hydroxides are characterized with relatively high values of specific surface $\left(220-300 \mathrm{~m}^{2} \mathrm{~g}^{-1}\right)$. All hydroxides, except of this from III $59 \mathrm{~h}$, have higher values of specific surface in comparison with the respective hydroxides prepared without the digestion step. During the process of ageing, the hydrolysis of basic aluminium salts takes place together with the removal of surface $\mathrm{OH}$ groups resulting in developing of crystal structure $[7,11]$. When water is removed from the interlayer space pores develop, the formation of bigger and more ordered primary particles of aluminium hydroxide takes place which consequently leads to the increase of specific surface for the samples of digested hydroxides. It explains higher values of specific surface for digested hydroxides from I $20 \mathrm{~h}, \mathrm{I} \backslash 39 \mathrm{~h}$, I $59 \mathrm{~h}$ and II $\backslash 59 \mathrm{~h}$ series in comparison with the samples not subjected to ageing ( $\mathrm{\backslash} \backslash \mathrm{h}$ and $\mathrm{II} \backslash 59 \mathrm{~h}$ ).

Musić et al. [8] investigating an influence of digestion time on the crystallinity of boehmite and its surface development noticed the decrease of the specific surface value from 164 to $146 \mathrm{~m}^{2} \mathrm{~g}^{-1}$ with lengthening time of digestion from 1 to $6 \mathrm{~h}$. Samples aged for longer time intervals $(24,72$ or $86 \mathrm{~h}$ ) had better and better formed crystal structure, however lower and lower value of specific surface $\left(S_{\mathrm{BET}}=91 \mathrm{~m}^{2} \mathrm{~g}^{-1}\right.$ for the sample digested for $86 \mathrm{~h}$ ). Taking this observation into consideration, one may suppose that for the samples from the $\mathrm{I}^{\text {st }}$ series, a fully crystallized boehmite struc- ture is not formed completely, which is confirmed by increasing values of specific surface for the hydroxides from $\mathrm{I} \backslash 20 \mathrm{~h}, \mathrm{I} \backslash 39 \mathrm{~h}$ and $\mathrm{I} \backslash 59 \mathrm{~h}$ series.

All hydroxides from the $\mathrm{I}^{\text {st }}-\mathrm{III}^{\text {rd }}$ series decrease their specific surface after calcination at 550, 900 or $1200^{\circ} \mathrm{C}$. However, aluminium oxides obtained by heating at 550 or $900^{\circ} \mathrm{C}$ maintain relatively high values of $S_{\mathrm{BET}}$, from 210 to $261 \mathrm{~m}^{2} \mathrm{~g}^{-1}$ for the samples calcined at $550^{\circ} \mathrm{C}$, and from 118 to $169 \mathrm{~m}^{2} \mathrm{~g}^{-1}$ for the samples calcined at $900^{\circ} \mathrm{C}$. Such high values of specific surface are typical for metastable aluminium oxides [15], whose formation is proved by the results of IR spectroscopy.

The analysis of the data collected in Table 2 shows that regardless of the number of series, $S_{\mathrm{BET}}$ measured for the oxides prepared from digested hydroxides are very similar to the values for the respective samples obtained without the digestion step. An increase of calcination temperature up to $1200^{\circ} \mathrm{C}$ results in a prominent decrease of specific surface values. The IR spectra denoted that at this temperature high-temperature transition aluminium oxides such as $\theta$ - or $\alpha-\mathrm{Al}_{2} \mathrm{O}_{3}$ are formed (Fig. 2c), which is accompanied by the sintering of powder particles, as well as devastation of their internal porosity. The highest values of $S_{\mathrm{BET}}$ are retained for the oxides from the III $^{\text {rd }}$ series (about $50 \mathrm{~m}^{2} \mathrm{~g}^{-1}$ ) containing the most $\theta$ phase and at the same time - the least $\alpha-\mathrm{Al}_{2} \mathrm{O}_{3}$. Furthermore, all aluminium oxides of individual series obtained through heating at $1200^{\circ} \mathrm{C}$ are characterised by congenial values of $S_{\mathrm{BET}}$, regardless of the fact whether the hydroxides, from which the oxides were derived, were digested or not. Prolonging digestion time from 20 to $59 \mathrm{~h}$ causes hardly any effect on the values of specific surface. On the base of these two notices, one may come to conclusion that these are the precipitation conditions, but not a digestion process or its duration, that influence a degree of surface development of aluminium oxides calcined at $1200^{\circ} \mathrm{C}$.

\section{Adsorption and desorption of benzene vapours}

The exemplary adsorption and desorption isotherms of benzene vapours are shown in Figs $3 a$ and b, whereas parameters of the porous structure calculated from them are collected in Table 2.

The shape of isotherms obtained for the hydroxides and oxides from I $\backslash 0 \mathrm{~h}, \mathrm{II} \backslash 0 \mathrm{~h}, \mathrm{II} \backslash 59 \mathrm{~h}$ and III $\backslash 0 \mathrm{~h}$ series (Fig. 3a) may be classified according to IUPAC nomenclature as the $\mathrm{H} 3$ type [19]. For the materials of this kind, a hysteresis loop is qualified by capillary condensation between two layers. Thus, in these samples bottle shape pores predominate. The isotherms obtained for the hydroxide and oxides (except from the aluminium oxide calcined at $1200^{\circ} \mathrm{C}$ ) from $\mathrm{I} \backslash 59 \mathrm{~h}$ 
INFLUENCE OF ALUMINIUM PRECURSOR ON ALUMINIUM HYDROXIDES AND OXIDES

Table 2 Porous structure parameters for selected samples determined by low-temperature nitrogen adsorption and adsorption $\backslash$ desorption of benzene vapours

\begin{tabular}{|c|c|c|c|c|c|}
\hline \multirow[b]{2}{*}{ Sample } & \multirow{2}{*}{$\begin{array}{l}\text { Specific } \\
\text { surface } \\
\text { (nitrogen) }\end{array}$} & \multicolumn{2}{|c|}{ Specific surface (benzene) } & \multicolumn{2}{|c|}{ Surface of mesopores (Kisielev method) } \\
\hline & & $S_{\mathrm{BET}(\text { vertical })} / \mathrm{m}^{2} \mathrm{~g}^{-1}$ & $S_{\text {BET(planar) }} / \mathrm{m}^{2} \mathrm{~g}^{-1}$ & $S_{\mathrm{MEZ}(\text { adsorption) }} / \mathrm{m}^{2} \mathrm{~g}^{-1}$ & $S_{\mathrm{MEZ}(\text { desorption) }} / \mathrm{m}^{2} \mathrm{~g}^{-1}$ \\
\hline \multicolumn{6}{|c|}{$\mathrm{I}^{\text {st }}$ series } \\
\hline $\mathrm{Al}(\mathrm{OH})_{3} \backslash 0 \mathrm{~h}$ & 244 & 179 & 286 & 155 & 241 \\
\hline $\mathrm{Al}_{2} \mathrm{O}_{3} \backslash 0 \mathrm{~h} \backslash 550^{\circ} \mathrm{C}$ & 214 & 132 & 211 & 195 & 270 \\
\hline $\mathrm{Al}_{2} \mathrm{O}_{3} \backslash 0 \mathrm{~h} \backslash 550^{\circ} \mathrm{C} \backslash 900^{\circ} \mathrm{C}$ & 131 & 87 & 140 & 142 & 194 \\
\hline $\mathrm{Al}_{2} \mathrm{O}_{3} \backslash 0 \mathrm{~h} \backslash 550^{\circ} \mathrm{C} \backslash 1200^{\circ} \mathrm{C}$ & 21 & 13 & 21 & $*$ & $*$ \\
\hline $\mathrm{Al}(\mathrm{OH})_{3} \backslash 20 \mathrm{~h}$ & 260 & - & - & - & - \\
\hline $\mathrm{Al}_{2} \mathrm{O}_{3} \backslash 20 \mathrm{~h} \backslash 550^{\circ} \mathrm{C}$ & 217 & - & - & - & - \\
\hline $\mathrm{Al}_{2} \mathrm{O}_{3} \backslash 20 \mathrm{~h} \backslash 550^{\circ} \mathrm{C} \backslash 900^{\circ} \mathrm{C}$ & 118 & - & - & - & - \\
\hline $\mathrm{Al}_{2} \mathrm{O}_{3} \backslash 20 \mathrm{~h} \backslash 550^{\circ} \mathrm{C} \backslash 1200^{\circ} \mathrm{C}$ & 21 & - & - & - & - \\
\hline $\mathrm{Al}(\mathrm{OH})_{3} \backslash 39 \mathrm{~h}$ & 261 & - & - & - & - \\
\hline $\mathrm{Al}_{2} \mathrm{O}_{3} \backslash 39 \mathrm{~h} \backslash 550^{\circ} \mathrm{C}$ & 220 & - & - & - & - \\
\hline $\mathrm{Al}_{2} \mathrm{O}_{3} \backslash 39 \mathrm{~h} \backslash 550^{\circ} \mathrm{C} \backslash 900^{\circ} \mathrm{C}$ & 143 & - & - & - & - \\
\hline $\mathrm{Al}_{2} \mathrm{O}_{3} \backslash 39 \mathrm{~h} \backslash 550^{\circ} \mathrm{C} \backslash 1200^{\circ} \mathrm{C}$ & 31 & - & - & - & - \\
\hline $\mathrm{Al}(\mathrm{OH})_{3} \backslash 59 \mathrm{~h}$ & 267 & 215 & 344 & 222 & 322 \\
\hline $\mathrm{Al}_{2} \mathrm{O}_{3} \backslash 59 \mathrm{~h} \backslash 550^{\circ} \mathrm{C}$ & 215 & 157 & 251 & 207 & 295 \\
\hline $\mathrm{Al}_{2} \mathrm{O}_{3} \backslash 59 \mathrm{~h} \backslash 550^{\circ} \mathrm{C} \backslash 900^{\circ} \mathrm{C}$ & 145 & 93 & 149 & 187 & 250 \\
\hline $\mathrm{Al}_{2} \mathrm{O}_{3} \backslash 59 \mathrm{~h} \backslash 550^{\circ} \mathrm{C} \backslash 1200^{\circ} \mathrm{C}$ & 23 & 16 & 26 & $*$ & $*$ \\
\hline \multicolumn{6}{|c|}{ II $^{\text {nd }}$ series } \\
\hline $\mathrm{Al}(\mathrm{OH})_{3} \backslash 0 \mathrm{~h}$ & 222 & 171 & 274 & 349 & 504 \\
\hline $\mathrm{Al}_{2} \mathrm{O}_{3} \backslash 0 \mathrm{~h} \backslash 550^{\circ} \mathrm{C}$ & 211 & 138 & 221 & 279 & 351 \\
\hline $\mathrm{Al}_{2} \mathrm{O}_{3} \backslash 0 \mathrm{~h} \backslash 550^{\circ} \mathrm{C} \backslash 900^{\circ} \mathrm{C}$ & 146 & 115 & 184 & 273 & 348 \\
\hline $\mathrm{Al}_{2} \mathrm{O}_{3} \backslash 0 \mathrm{~h} \backslash 550^{\circ} \mathrm{C} \backslash 1200^{\circ} \mathrm{C}$ & 28 & 18 & 29 & $*$ & $*$ \\
\hline $\mathrm{Al}(\mathrm{OH})_{3} \backslash 59 \mathrm{~h}$ & 256 & 209 & 334 & 269 & 408 \\
\hline $\mathrm{Al}_{2} \mathrm{O}_{3} \backslash 59 \mathrm{~h} \backslash 550^{\circ} \mathrm{C}$ & 210 & 130 & 207 & 255 & 338 \\
\hline $\mathrm{Al}_{2} \mathrm{O}_{3} \backslash 59 \mathrm{~h} \backslash 550^{\circ} \mathrm{C} \backslash 900^{\circ} \mathrm{C} \backslash$ & 138 & 95 & 153 & 252 & 297 \\
\hline $\mathrm{Al}_{2} \mathrm{O}_{3} \backslash 59 \mathrm{~h} \backslash 550^{\circ} \mathrm{C} \backslash 1200^{\circ} \mathrm{C}$ & 38 & 30 & 47 & $*$ & $*$ \\
\hline \multicolumn{6}{|c|}{$\mathrm{III}^{\mathrm{rd}}$ series } \\
\hline $\mathrm{Al}(\mathrm{OH})_{3} \backslash 0 \mathrm{~h}$ & 297 & 201 & 321 & 385 & 584 \\
\hline $\mathrm{Al}_{2} \mathrm{O}_{3} \backslash 0 \mathrm{~h} \backslash 550^{\circ} \mathrm{C}$ & 261 & 184 & 295 & 556 & 728 \\
\hline $\mathrm{Al}_{2} \mathrm{O}_{3} \backslash 0 \mathrm{~h} \backslash 550^{\circ} \mathrm{C} \backslash 900^{\circ} \mathrm{C}$ & 169 & 100 & 160 & 375 & 375 \\
\hline $\mathrm{Al}_{2} \mathrm{O}_{3} \backslash 0 \mathrm{~h} \backslash 550^{\circ} \mathrm{C} \backslash 1200^{\circ} \mathrm{C}$ & 53 & 35 & 56 & $*$ & $*$ \\
\hline $\mathrm{Al}(\mathrm{OH})_{3} \backslash 59 \mathrm{~h}$ & 252 & 182 & 291 & 433 & 531 \\
\hline $\mathrm{Al}_{2} \mathrm{O}_{3} \backslash 59 \mathrm{~h} \backslash 550^{\circ} \mathrm{C}$ & 235 & 143 & 228 & 476 & 736 \\
\hline $\mathrm{Al}_{2} \mathrm{O}_{3} \backslash 59 \mathrm{~h} \backslash 550^{\circ} \mathrm{C} \backslash 900^{\circ} \mathrm{C}$ & 147 & 84 & 134 & 378 & 773 \\
\hline $\mathrm{Al}_{2} \mathrm{O}_{3} \backslash 59 \mathrm{~h} \backslash 550^{\circ} \mathrm{C} \backslash 1200^{\circ} \mathrm{C}$ & 48 & 41 & 65 & $*$ & $*$ \\
\hline
\end{tabular}

*lack of hysteresis loop

series (Fig. 3b) are characterised with the shape congenial with the $\mathrm{H} 2$ type. Such a hysteresis loop corresponds to pores with shape resembling an 'inkstand' and to spherical pores open from both ends with significant inside necks.

The values of specific surface presented in Table 2, show that the aluminium hydroxides from $\mathrm{I}^{\text {st }}-\mathrm{III}^{\text {rd }}$ series have good adsorption capacity for ben- zene vapours. $S_{\mathrm{BET}}$ values calculated supposing planar orientation of benzene molecules in adsorption monolayer are close to $300 \mathrm{~m}^{2} \mathrm{~g}^{-1}$. So high values of mesopore surface, in case of the samples from $\mathrm{II}^{\text {nd }}$ and $\mathrm{III}^{\text {rd }}$ series - much higher than $S_{\mathrm{BET} \text { (planar) }}$, as well as broad hysteresis loops evidence their developed mesoporous structure. 


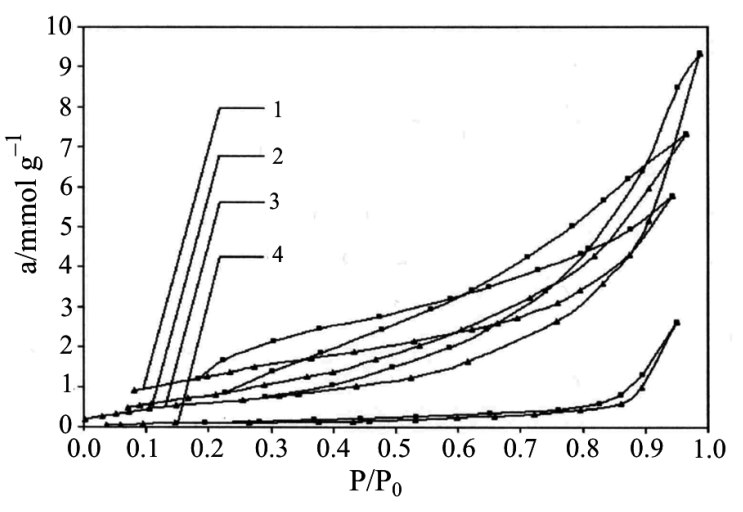

Fig. 3a The adsorption/desorption isotherms of benzene vapours for the samples from the $\mathrm{I} \backslash 0 \mathrm{~h}$ series; $1-\mathrm{Al}(\mathrm{OH})_{3} \backslash I \backslash 0 \mathrm{~h}, 2-\mathrm{Al}_{2} \mathrm{O}_{3} \backslash \backslash \backslash 0 \mathrm{~h} \backslash 550^{\circ} \mathrm{C}$, $3-\mathrm{Al}_{2} \mathrm{O}_{3} \backslash \backslash \backslash 0 \mathrm{~h} \backslash 550^{\circ} \mathrm{C} \backslash 900^{\circ} \mathrm{C}$, $4-\mathrm{Al}_{2} \mathrm{O}_{3} \backslash \mathrm{I} \backslash 0 \mathrm{~h} \backslash 550^{\circ} \mathrm{C} \backslash 1200^{\circ} \mathrm{C}$

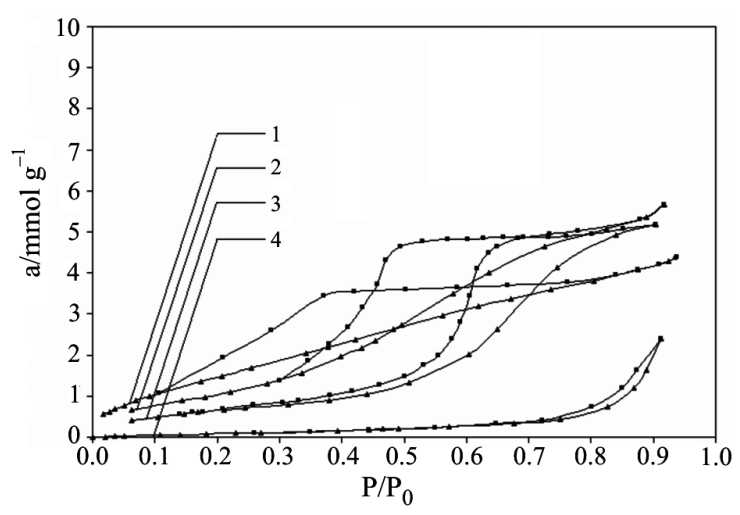

Fig. 3b The adsorption/desorption isotherms of benzene vapours for the samples from the I $\backslash 59 \mathrm{~h}$ series; $1-\mathrm{Al}(\mathrm{OH})_{3} \backslash \mathrm{I} \backslash 59 \mathrm{~h}, 2-\mathrm{Al}_{2} \mathrm{O}_{3} \backslash \mathrm{I} \backslash 59 \mathrm{~h} \backslash 550^{\circ} \mathrm{C}$, $3-\mathrm{Al}_{2} \mathrm{O}_{3} \backslash \mathrm{I} \backslash 59 \mathrm{~h} \backslash 550^{\circ} \mathrm{C} \backslash 900^{\circ} \mathrm{C}$, $4-\mathrm{Al}_{2} \mathrm{O}_{3} \backslash \mathrm{I} \backslash 59 \mathrm{~h} \backslash 550^{\circ} \mathrm{C} \backslash 1200^{\circ} \mathrm{C}$

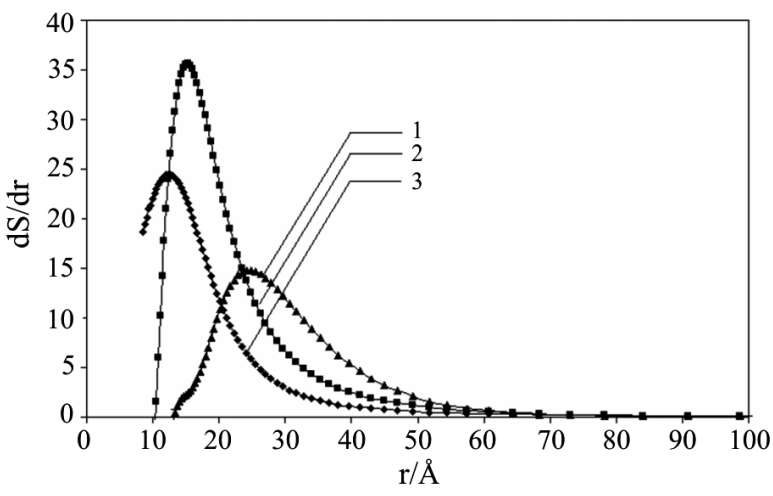

Fig. 3c The distribution of mesopore surface area as a function of the effective radii for the samples from the I $\backslash 59$ h series; $1-\mathrm{Al}(\mathrm{OH})_{3} \backslash \mathrm{I} \backslash 59 \mathrm{~h}$, $2-\mathrm{Al}_{2} \mathrm{O}_{3} \backslash \mathrm{I} \backslash 59 \mathrm{~h} \backslash 550^{\circ} \mathrm{C}, 3-\mathrm{Al}_{2} \mathrm{O}_{3} \backslash \mathrm{I} \backslash 59 \mathrm{~h} \backslash 550^{\circ} \mathrm{C} \backslash 900^{\circ} \mathrm{C}$

The process of calcination at $550-900^{\circ} \mathrm{C}$ leads to decreasing values of $S_{\mathrm{BET}}$, however, regardless of the series number and digestion time, the materials maintain a mesoporous character. Aluminium oxides calcined at $1200^{\circ} \mathrm{C}$ have significantly lower adsorption

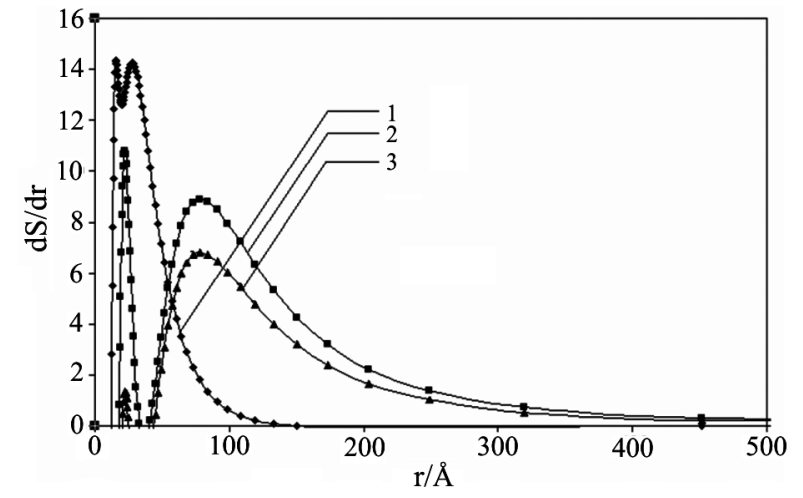

Fig. 3d The distribution of mesopore surface area as a function of the effective radii for the samples from the III $159 \mathrm{~h}$ series; $1-\mathrm{Al}(\mathrm{OH})_{3} \backslash \mathrm{IIII} \backslash 59 \mathrm{~h}, 2-\mathrm{Al}_{2} \mathrm{O}_{3} \backslash \mathrm{III} \backslash 59 \mathrm{~h} \backslash 550^{\circ} \mathrm{C}$, $3-\mathrm{Al}_{2} \mathrm{O}_{3} \backslash \mathrm{III} \backslash 59 \mathrm{~h} \backslash 550^{\circ} \mathrm{C} \backslash 900^{\circ} \mathrm{C}$

capacity for benzene vapours, which is confirmed by vanishing or emphatic narrowing of hysteresis loop, the lowest placed adsorption isotherms, and in consequence, low values of specific surface. Within all oxides calcined at $1200^{\circ} \mathrm{C}$, the samples from III $\backslash 0 \mathrm{~h}$ and III $\ 59 \mathrm{~h}$ series have the highest $S_{\mathrm{BET}}$ values (56 and $65 \mathrm{~m}^{2} \mathrm{~g}^{-1}$, respectively).

A comparative analysis of nitrogen and benzene adsorption results gives the possibility of estimating the hydrophilic-hydrophobic properties of aluminium hydroxides and oxides $[20,21]$. These properties depend on the surface functional groups that are for the different orientation of benzene molecules sorbed and for the degree of their packing in the adsorption layer. The nitrogen molecule (inert gas) has a small seating surface $\left(0.16 \mathrm{~nm}^{2}\right)$ as compared with that of benzene molecule $\left(0.25 \mathrm{~nm}^{2}\right.$ in the vertical orientation and $0.40 \mathrm{~nm}^{2}$ in the planar orientation). For this reason, if the surface structure is favourable for the planar orientation of benzene molecule, the specific surface $S_{\mathrm{BET}(\text { planar) }}$ should be smaller or equal to the $S_{\mathrm{BET}}$ value determined from the adsorption of nitrogen. Excessive values of $S_{\mathrm{BET}(\mathrm{planar})}$ with respect to the specific surface values determined from nitrogen adsorption may be accounted for the decrease of the surface accessible for seating of benzene molecules, which can be a result of the change in orientation of its molecules in adsorption layer. The deviation of benzene molecules on the surface of hydroxides and oxides is likely to be caused by surface hydroxyl groups.

Regardless of the series, $S_{\mathrm{BET}(\text { planar) }}$ values calculated for starting hydroxides are much higher than those of $S_{\mathrm{BET}}$ determined from nitrogen adsorption. It may be the evidence of a prominent concentration of hydroxyl groups on the surface of studied materials enabling deviation of adsorbed benzene molecules from planar orientation. Thus, the hydroxides are of hydrophilic character. 
The process of calcination at $550-1200^{\circ} \mathrm{C}$ results in decreasing a discrepancy between the values of $S_{\mathrm{BET}}$ determined from benzene and nitrogen adsorption, which may prove surface dehydroxylation of the samples, and in consequence, an increasing degree of hydrophobicity. For the samples calcined at $1200^{\circ} \mathrm{C}$, it is possible to assume that benzene molecules have planar orientation in monomolecular adsorption layer.

The distribution of mesopore surface (Figs 3c and d) as a function of effective radii was determined by the Dollimore-Hill's method with assumption of the model of cylindrical pores, open from both sides, for quartz as the adsorption layer.

It has been found that the pores of radii within 12-25 \& contribute the most to the porosity of the samples from I $\backslash 0 \mathrm{~h}, \mathrm{I} \backslash 59 \mathrm{~h}$ and II $\backslash 59 \mathrm{~h}$ series (Fig. 3c), however, an increase of the calcination temperature leads to enhanced contribution of pores with bigger radii. These samples are characterized with monodispersive distribution of the pores. The bimodal nature of pore distribution is observed for the sample from II $\backslash 0 \mathrm{~h}$ series calcined at $900^{\circ} \mathrm{C}$ (maximum values for pore radii equal 18 and $30 \AA$ ), as well as for the samples for III $\backslash 59 \mathrm{~h}$ series calcined at 550 or $900^{\circ} \mathrm{C}$ (Fig. 3d). For the last mentioned samples, one may note an audible increase of the contribution of pores with radii within $22-75 \AA$.

\section{Conclusions}

- The hydrolysis of hydrous aluminium chloride in ammonia medium results in the formation of boehmite.

- A high $\mathrm{pH}$ value during a precipitation process, as well as the digestion at elevated temperature of precipitated aluminium hydroxides favour better crystallisation of boehmite structure; however prolonging of ageing duration (from 20 to $59 \mathrm{~h}$ ) has a slight effect on the increase of boehmite amount in the samples.

- The boehmite samples have high values of $S_{\mathrm{BET}}$ determined by the method of low-temperature nitrogen adsorption (220-300 $\left.\mathrm{m}^{2} \mathrm{~g}^{-1}\right)$, good adsorption capacity for benzene vapours, developed mesoporous structure and hydrophilic character.

- Obtained aluminium hydroxides during calcination at the temperature up to $1200^{\circ} \mathrm{C}$ transform to $\alpha-\mathrm{Al}_{2} \mathrm{O}_{3}$ via $\gamma$ - and $\theta-\mathrm{Al}_{2} \mathrm{O}_{3}$; however a high $\mathrm{pH}$ value during the precipitation favours higher temperature of boehmite dehydroxylation into $\gamma-\mathrm{Al}_{2} \mathrm{O}_{3}$ and delayed transformation of $\gamma-\mathrm{Al}_{2} \mathrm{O}_{3}$ into $\alpha-\mathrm{Al}_{2} \mathrm{O}_{3}$.

- An increase of calcination temperature from 550 to $1200^{\circ} \mathrm{C}$ leads to decreasing of $S_{\mathrm{BET}}$ values determined from low-temperature adsorption of nitrogen and adsorption capacity of benzene vapours, and to increasing of the degree of sample hydrophobicity.

- The samples of aluminium oxides derived from aluminium hydroxides precipitated at a high $\mathrm{pH}$ value $(\mathrm{pH}=8)$ are the most stable at high temperatures and are characterized with the best surface properties $\left(S_{\mathrm{BET}}\right.$ values determined from low-temperature adsorption of nitrogen and adsorption of benzene vapours are about $50 \mathrm{~m}^{2} \mathrm{~g}^{-1}$ ).

\section{References}

1 R. Mezei and K. Sinkó, Colloid Polym. Sci., 274 (1996) 1054.

2 H. K. Varma, K. G. K. Warrier and A. D. Damodaran, Ceram. Int., (1990).

3 K. T. Hwang, H. S. Lee, S. H. Lee, K. C. Chung, S. S. Park and J. H. Lee, J. Eur. Ceram. Soc., 21 (2001) 375.

4 S. Musić, Đ. Dragčević, S. Popović and N. Vdović, Mater. Sci. Eng., B 52 (1998) 145.

5 J.-F. Hochepied and P. Nortier, Powder Tech., 128 (2002) 268.

6 B. Pacewska, M. Keshr and O. Kluk-Płoskońska, J. Therm. Anal. Cal., 74 (2003) 595.

7 G. K. Chuagh, S. Jaenicke and T. H. Xu, Microporous Mesoporous Mater., 37 (2000) 345.

8 S. Musić, Đ. Dragčević and S. Popović, Mater. Lett., 40 (1999) 269.

9 B. Pacewska, D. Szychowski and T. Żmijewski, Computer program for evaluation of parameters of porous structure of solids, Forum Chemiczne 2000, Warszawa 2000.

10 J. Temuujin, Ts. Jadambaa, K. J. D. Mackenzie, P. Angerer, F. Porte and F. Riley, Bull. Mater. Sci., (2000) 301.

11 S. Desset, O. Spalla, P. Lixon and B. Cabane, Colloids and Surfaces A: Physicohemical and Engineering Aspects, 196 (2002) 1.

12 J. J. Fripiat, H. Bosmans and P. G. Rouxhet, J. Phys. Chem., 71 (1967) 1097.

13 R. L. Frost, J. Kloprogge, S. C. Russell and J. L. Szetu, Thermochim. Acta, 329 (1999) 47.

14 E. Ingier-Stocka, C. Mazanek, L. Rycerz and R. Wojciechowska, Wodorotlenki i tlenki glinu. Właściwości i technologia ich otrzymywania, Wydawnictwo Politechniki Wrocławskiej, Wrocław 1984.

15 S. Musić, Đ. Dragčević, S. Popović and N. Vdović, Mater. Chem. Phys., 59 (1999) 12.

16 C. Morterra and G. Magnacca, Catal. Today, 27 (1996) 497.

17 J. T. Kloprogge and R. L. Frost, Spectrochim. Acta Part A, 55 (1999) 163.

18 R. Ziniuk, A. G. Balikow, I. B. Gawrylenko, A. M. Shewiakow, IR-Spectroscopy in Inorganic Technology, Chemistry, Leningrad 1983 (in Russian).

19 IUPAC Reporting Physisorption Data, Pure Appl. Chem., 57 (1985) 603.

20 B. Pacewska and D. Szychowski, Przemysł Chemiczny (submitted for publication).

21 B. Pacewska and D. Szychowski, J. Therm. Anal. Cal., 80 (2005) 687.

Received: March 25, 2005

Accepted: May 24, 2005

OnlineFirst: January 11, 2006

DOI: 10.1007/s10973-005-7016-x 